\title{
Extracorporeal membrane oxygenation 2016: an update
}

\section{[version 1; peer review: 3 approved]}

\section{Warwick Butt1-3, Graeme MacLaren 1,2,4}

\author{
${ }^{1}$ Paediatric Intensive Care Unit, Royal Children's Hospital, Parkville, VIC, 3052, Australia \\ ${ }^{2}$ Department of Paediatrics, University of Melbourne, Melbourne, VIC, Australia \\ ${ }^{3}$ Murdoch Children's Research Institute, Clinical Sciences, Melbourne, Australia \\ ${ }^{4}$ Cardiothoracic Intensive Care Unit, National University Health System, 5 Lower Kent Ridge Road, 119074, Singapore
}

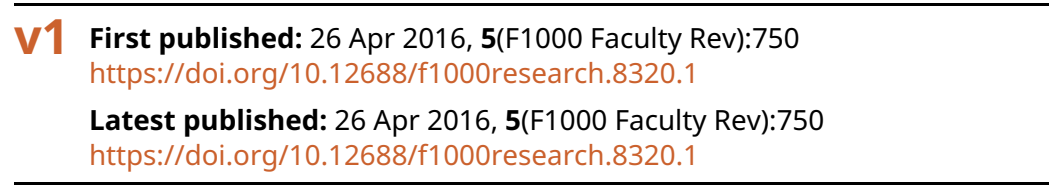

\section{Abstract}

The use of extracorporeal membrane oxygenation (ECMO) is an important issue for intensivists, critical care nurses, surgeons, cardiologists, and many others. There has been a continued increase in the number of centres performing ECMO. This review examines novel applications and recent trends in the use of ECMO over the last 2 years. These include ECMO to facilitate the safe use of other treatments, changing the timing of initiation, newer equipment and better biocompatibility, and the ability of ECMO programs to essentially choose which cluster of potential complications they are prepared to accept. ECMO continues to evolve, diversify in its applications, and improve in safety.

\section{Keywords}

fulminant respiratory failure, neonatal respiratory failure, severe pulmonary hypertension, cardiac failure, mechanical circulatory support, Extra Corporeal Life Support,

\section{Open Peer Review}

Approval Status

12

3

version 1

26 Apr 2016

Faculty Reviews are review articles written by the prestigious Members of Faculty Opinions. The articles are commissioned and peer reviewed before publication to ensure that the final, published version is comprehensive and accessible. The reviewers who approved the final version are listed with their names and affiliations.

1. Gail Annich, Toronto Hospital for Sick Children, Toronto, Canada

2. Margaret Parker, State University of New York at Stony Brook, Stony Brook, USA

3. Niranjan T. Kissoon, BC Children's Hospital and University of British Columbia,

Vancouver, Canada

Any comments on the article can be found at the end of the article. 
Corresponding author: Graeme MacLaren (gmaclaren@iinet.net.au)

Competing interests: The authors declare that they have no competing interests.

Grant information: The author(s) declared that no grants were involved in supporting this work.

Copyright: $\odot 2016$ Butt W and MacLaren G. This is an open access article distributed under the terms of the Creative Commons Attribution License, which permits unrestricted use, distribution, and reproduction in any medium, provided the original work is properly cited.

How to cite this article: Butt W and MacLaren G. Extracorporeal membrane oxygenation 2016: an update [version 1; peer review: 3 approved] F1000Research 2016, 5(F1000 Faculty Rev):750 https://doi.org/10.12688/f1000research.8320.1

First published: 26 Apr 2016, 5(F1000 Faculty Rev):750 https://doi.org/10.12688/f1000research.8320.1 


\section{Introduction}

Extracorporeal membrane oxygenation (ECMO) was developed as a treatment for fulminant respiratory failure (hence its name) in adults in the early 1970s by removing venous blood from the body, adding oxygen, removing carbon dioxide, and returning it to the patient. This therapy was limited to 5 days, and vascular access was obtained by cannulation of the femoral artery and vein. Subsequently, in the early 1980s, this veno-arterial mode was changed to veno-venous, but only a few centres persisted with the technology because bleeding and poor outcomes were common. Similarly, in children, ECMO was first used for neonatal respiratory failure, but, in newborns and young children, severe pulmonary hypertension and poor cardiac function often accompanied respiratory failure. Hence, its use for mechanical circulatory support when isolated cardiac failure occurred was a logical extension. In adults, after cardiac surgery, intra-aortic balloon pumps were commonly used as mechanical circulatory support, but these were very difficult to use successfully in small children (because of the child's high heart rate and smaller blood vessels). Therefore, veno-arterial ECMO was used in children with cardiac failure, and ECMO became extra-corporeal life support. In the 2000s, a better understanding of the pathophysiology of ECMO and diseases for which it was used led to a rapid re-emergence of this as a therapy for all patients with cardio-respiratory failure; various modifications allowed single or biventricular support, oxygenation or carbon dioxide removal, for short or longer periods of time. This was extensively reviewed in F1000Prime Reports 2013; the concluding paragraph in that review stated that "ECMO is a standard therapy in critical care. It is used as a treatment for acute severe cardiorespiratory failure and as a resuscitation strategy in many clinical scenarios. It is also used as a 'bridge' to other treatments and transplantation. It continues to be applied to more complex and chronic situations. It is being integrated into multiple-organ support therapies. Substantial improvements in biotechnology and clinical practices over the last 40 years have allowed ECMO to provide a vital role in acute organ support in patients of all ages. It is likely that further such advances will diminish complication rates, facilitate more widespread adoption of the technology in middle- and high-income countries, and improve outcomes from refractory heart, lung, and multiorgan failure"'.

Over the last 2 years, the use of ECMO continues to be an important issue for clinicians: a literature search with ECMO as a key word and including only English language articles and publication dates from 2014 to 2015 yielded 932 articles, 123 reviews, and 16 editorials. During this period, there have also been continued increases in the number of centres performing ECMO (Figure 1) and in the amount of paediatric and neonatal use in children with cardiac disease as well as a large increase in the use of ECMO for adult respiratory and cardiac disease (Table 1). The latest cumulative survival reported by the Extracorporeal Life Support Organization is shown in Table 2. The last 2 years have revealed many new uses and issues involving ECMO. These are summarised in the sections below.

\section{Centres experimenting with new applications of extracorporeal membrane oxygenation}

The most important issues in the last few years for clinicians involved in ECMO depend on the type and experience of the ECMO program and the hospital in which ECMO is performed. New programs are focusing on standard uses of ECMO, systems for safe use and deployment of ECMO, management of patients on ECMO, understanding indications and contraindications, education, and simulation. Long-standing programs, on the other hand, are focusing on improving outcomes by considering alternative ECMO strategies (such as normal or high flow for septic shock, different types of peripheral or trans-thoracic cannulation, and initiating ECMO earlier) or different patient groups that

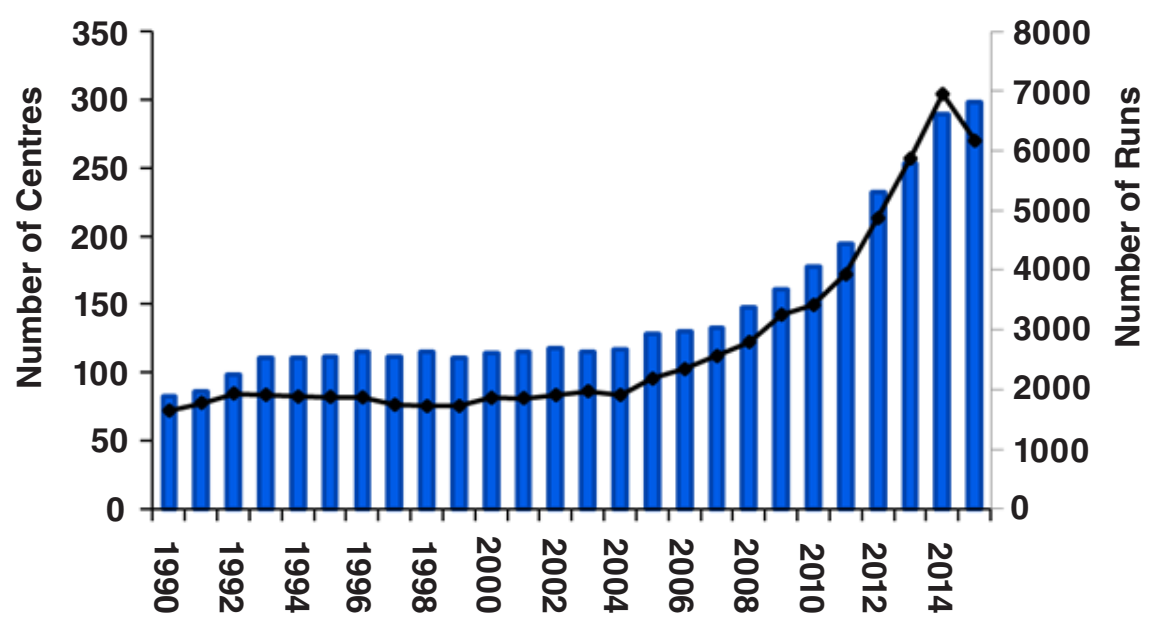

Figure 1. Active extracorporeal membrane oxygenation centres and patients reported to the Extracorporeal Life Support Organization $^{20}$. 
Table 1. Extracorporeal membrane oxygenation use in runs per year (percent survival) over the last 5 years ${ }^{20}$.

\begin{tabular}{|c|c|c|c|c|c|}
\hline & 2011 & 2012 & 2013 & 2014 & 2015 \\
\hline \multicolumn{6}{|l|}{ Respiratory } \\
\hline $\begin{array}{l}\text { Neonatal and } \\
\text { paediatric }\end{array}$ & $1,258(64 \%)$ & $1,322(67 \%)$ & $1,277(65 \%)$ & $1,364(67 \%)$ & $1,072(62 \%)$ \\
\hline Adult & $672(59 \%)$ & $952(57 \%)$ & $1,442(60 \%)$ & $1,899(61 \%)$ & $1,568(57 \%)$ \\
\hline \multicolumn{6}{|l|}{ Cardiac } \\
\hline$<16$ years old & $889(52 \%)$ & $916(52 \%)$ & $978(50 \%)$ & $1,063(50 \%)$ & 807 (50\%) \\
\hline$\geq 16$ years old & $604(37 \%)$ & $1,033(41 \%)$ & $1,253(42 \%)$ & $1,679(43 \%)$ & $1,769(41 \%)$ \\
\hline
\end{tabular}

\section{Table 2. Cumulative extra-corporeal life support survival ${ }^{20}$.}

\begin{tabular}{|l|l|c|c|}
\hline & $\begin{array}{c}\text { Total } \\
\text { patients }\end{array}$ & $\begin{array}{c}\text { Survived extra- } \\
\text { corporeal life } \\
\text { support }\end{array}$ & $\begin{array}{c}\text { Survived } \\
\text { to hospital } \\
\text { discharge }\end{array}$ \\
\hline Neonatal & & & \\
\hline Respiratory & 28,723 & $84 \%$ & $74 \%$ \\
\hline Cardiac & 6,269 & $62 \%$ & $41 \%$ \\
\hline ECPR & 1,254 & $64 \%$ & $41 \%$ \\
\hline Paediatric & & & \\
\hline Respiratory & 7,210 & $66 \%$ & $58 \%$ \\
\hline Cardiac & 8,021 & $67 \%$ & $51 \%$ \\
\hline ECPR & 2,788 & $55 \%$ & $41 \%$ \\
\hline Adult & & & \\
\hline Respiratory & 9,102 & $66 \%$ & $58 \%$ \\
\hline Cardiac & 7,850 & $56 \%$ & $41 \%$ \\
\hline ECPR & 2,379 & $40 \%$ & $30 \%$ \\
\hline
\end{tabular}

ECPR, extracorporeal cardiopulmonary resuscitation.

hitherto were not considered (such as patients with immune suppression or cancer, pregnant women ${ }^{2}$, or the elderly ${ }^{3}$ ). Perhaps more controversially, some centres have begun research in using it as a bridge to solid organ transplantation ${ }^{4}$, referred to as extracorporeal support-assisted organ donation. Once a patient has died in a controlled environment as part of a donation-after-cardiac death (DCD) strategy, an aortic balloon is inserted into the proximal descending aorta to prevent re-establishing cerebral blood flow and the patient is cannulated onto femoral-femoral ECMO. This improves abdominal organ metabolic support and has been associated with improved graft survival in the recipient ${ }^{5}$.
The use of extracorporeal membrane oxygenation to facilitate the safe use of other treatments

The safety and capacity to transport patients on ECMO now allow the consideration of the use of ECMO as a haemodynamically stable platform in order to facilitate complex surgery ${ }^{6}$ or interventional cardiology procedures ${ }^{7}$. Moreover, ECMO stabilises deranged cardiopulmonary physiology in unstable patients such that therapies deemed unsafe-haemodialysis in newborn infants or support of vital organ function during rewarming from accidental hypothermia, such as in avalanche victims ${ }^{8-10}$, for example-can be undertaken safely. Comparable to cardiopulmonary bypass facilitating safe cardiac surgery, ECMO provides a haemodynamically stable platform to facilitate these other therapies that otherwise might not be tolerated by the patient. Patients can have complex chemotherapy ${ }^{11}$ or immunotherapy regimens that cause a severe systemic inflammatory response and are supported with ECMO. ECMO is increasingly being used as a long-term bridge to facilitate lung transplantation ${ }^{12,13}$. The use of ECMO in adult cardiorespiratory failure to resuscitate from cardiogenic shock and transport to local cardiac surgical centres for long-term support with ventricular assist devices and transplant programs is also increasingly available $\mathrm{e}^{14,15}$.

When to initiate extracorporeal membrane oxygenation The implementation of ECMO is changing as the technology continues to improve. Rather than being used as a last resort or rescue therapy, it has become a standard therapy and increasingly is being implemented earlier in the course of disease in attempts to minimise multi-organ failure. The timing of initiation varies between centres and is a balance of risk for each particular program; it is not a case of better or worse but of the appropriate use of the therapy given each program's system of use. The realisation that increased survival occurred with earlier use of veno-venous ECMO is now being applied to veno-arterial ECMO in many centres. The role of ECMO in resuscitation and stabilisation of cardiac arrest or cardiogenic shock also varies. 


\section{New equipment for extracorporeal membrane oxygenation: cannulas and biocompatible circuits}

Newer cannulas with improved flow characteristics or more biocompatible plastics are being developed that will further improve the safety of ECMO. The ultimate goal is to have a circuit that is fully biocompatible with no need for anticoagulation and no risk of thromboembolism or haemorrhage. Excellent circuit flow characteristics and self-regulated flow-demand loops are only a generation away ${ }^{16-18}$.

\section{Choose your complication}

Currently, after weighing the benefits and risks to determine an approach that suits their needs, each program can essentially choose which cluster of potential complications they are prepared to accept. For instance, the type and extent of anticoagulation contribute to the likelihood of promoting either surgical bleeding or thromboembolism. A transthoracic cannulation approach leads to a higher incidence of bleeding and mediastinitis but also allows larger cannulas with increased flow. Jugular-carotid cannulation is more likely to cause cerebral thromboembolic and haemorrhagic complications than central cannulation ${ }^{19}$. Femoro-femoral cannulation is more likely to have differential hypoxemia or limb ischaemia than other types of cannulation. These are very important issues, as each program has a different cannulation strategy influenced by the skill set of the cannulating doctor; intensivists are different from general surgeons, who are different from cardiac surgeons. Comparison of results clearly requires knowledge of similarities and differences between programs.

\section{Conclusions}

ECMO continues to evolve, diversify in its applications, and improve in safety. Patient outcome is centre specific and very dependent on local factors, local indications, and contraindications. Evaluation of each centre's results should be done with these factors in mind; the ECMO community continues to share results and knowledge in an attempt to improve patient outcomes.

\section{Competing interests}

The authors declare that they have no competing interests.

\section{Grant information}

The author(s) declared that no grants were involved in supporting this work.
1. Butt W, Maclaren G: Extracorporeal membrane oxygenation. F1000Prime Rep. 2013; 5: 55 . PubMed Abstract | Publisher Full Text | Free Full Text

2. F Sharma NS, Wille KM, Bellot SC, et al.: Modern use of extracorporeal life support in pregnancy and postpartum. ASAIO J. 2015; 61(1): 110-4 PubMed Abstract | Publisher Full Text | F1000 Recommendation

3. F Mendiratta P, Tang X, Collins RT 2nd, et al:: Extracorporeal membrane oxygenation for respiratory failure in the elderly: a review of the Extracorporeal Life Support Organization registry. ASAIO J. 2014; 60(4): 385-90. PubMed Abstract | Publisher Full Text | F1000 Recommendation

4. F Oniscu GC, Randle LV, Muiesan P, et al.: In situ normothermic regional perfusion for controlled donation after circulatory death--the United Kingdom experience. Am J Transplant. 2014; 14(12): 2846-54. PubMed Abstract | Publisher Full Text | F1000 Recommendation

5. $\quad \mathrm{F}$ Carter $\mathrm{T}$, Bodzin AS, Hirose $\mathrm{H}$, et al:: Outcome of organs procured from donors on extracorporeal membrane oxygenation support: an analysis of kidney and liver allograft data. Clin Transplant. 2014; 28(7): 816-20. PubMed Abstract | Publisher Full Text | F1000 Recommendation

6. F Lang G, Ghanim B, Hötzenecker K, et al.: Extracorporeal membrane oxygenation support for complex tracheo-bronchial procedures ${ }^{\dagger}$. Eur $J$ Cardiothorac Surg. 2015; 47(2): 250-5; discussion 256. PubMed Abstract | Publisher Full Text | F1000 Recommendation

7. F Shebani SO, $\mathrm{Ng} \mathrm{GA}$, Stafford $P$, et al:: Radiofrequency ablation on venoarterial extracorporeal life support in treatment of very sick infants with incessant tachymyopathy. Europace. 2015; 17(4): 622-7. PubMed Abstract | Publisher Full Text | F1000 Recommendation

8. F Dunne B, Christou E, Duff O, et al:: Extracorporeal-assisted rewarming in the management of accidental deep hypothermic cardiac arrest: a systematic review of the literature. Heart Lung Circ. 2014; 23(11): 1029-35. PubMed Abstract | Publisher Full Text | F1000 Recommendation

9. Ruttmann E, Weissenbacher $\mathrm{A}$, Ulmer $\mathrm{H}$, et al:: Prolonged extracorporeal membrane oxygenation-assisted support provides improved survival in hypothermic patients with cardiocirculatory arrest. J Thorac Cardiovasc Surg. 2007; 134(3): 594-600.

PubMed Abstract | Publisher Full Text

10. F Sawamoto K, Bird SB, Katayama $Y$, et al:: Outcome from severe accidenta hypothermia with cardiac arrest resuscitated with extracorporeal cardiopulmonary resuscitation. Am J Emerg Med. 2014; 32(4): 320-4. PubMed Abstract | Publisher Full Text | F1000 Recommendation
11. F Worku B, DeBois W, Sobol I, et al.: Extracorporeal Membrane Oxygenation as a Bridge through Chemotherapy in B-Cell Lymphoma. J Extra Corpor Technol. 2015; 47(1): 52-4.

PubMed Abstract | Free Full Text | F1000 Recommendation

12. F Inci I, Klinzing S, Schneiter D, et al.: Outcome of Extracorporeal Membrane Oxygenation as a Bridge To Lung Transplantation: An Institutional Experience and Literature Review. Transplantation. 2015; 99(8): 1667-71. PubMed Abstract | Publisher Full Text | F1000 Recommendation

13. F Chiumello D, Coppola S, Froio S, et al.: Extracorporeal life support as bridge to lung transplantation: a systematic review. Crit Care. 2015; 19(1): 19. PubMed Abstract | Publisher Full Text | Free Full Text | F1000 Recommendation

14. F Pellegrino V, Hockings LE, Davies A: Veno-arterial extracorporeal membrane oxygenation for adult cardiovascular failure. Curr Opin Crit Care. 2014; 20(5): 484-92.

PubMed Abstract | Publisher Full Text | F1000 Recommendation

15. F Abrams D, Combes A, Brodie D: Extracorporeal membrane oxygenation in cardiopulmonary disease in adults. J Am Coll Cardiol. 2014; 63(25 Pt A): 2769-78. PubMed Abstract | Publisher Full Text | F1000 Recommendation

16. F Major TC, Brisbois EJ, Jones AM, et al:: The effect of a polyurethane coating incorporating both a thrombin inhibitor and nitric oxide on hemocompatibility in extracorporeal circulation. Biomaterials. 2014; 35(26): 7271-85. PubMed Abstract | Publisher Full Text | Free Full Text | F1000 Recommendation

17. F Stang K, Borchardt R, Neumann B, et al.: First In Vivo Results of a Novel Pediatric Oxygenator with an Integrated Pulsatile Pump. ASAIO J. 2015; 61(5): 574-82.

PubMed Abstract | Publisher Full Text | F1000 Recommendation

18. F Teman NR, Demos DS, Bryner BS, et al:: In vivo testing of a novel blood pump for short-term extracorporeal life support. Ann Thorac Surg. 2014; 98(1): 97-102.

PubMed Abstract | Publisher Full Text | Free Full Text | F1000 Recommendation

19. F Teele SA, Salvin JW, Barrett CS, et al.: The association of carotid artery cannulation and neurologic injury in pediatric patients supported with venoarterial extracorporeal membrane oxygenation*. Pediatr Crit Care Med. 2014; 15(4): 355-61.

PubMed Abstract | Publisher Full Text | F1000 Recommendation

20. Extracorporeal Life Support Organization: ECLS Registry Report. International Summary, Ann Arbor. 2016

Reference Source 


\section{Open Peer Review}

\section{Current Peer Review Status:}

\section{Editorial Note on the Review Process}

Faculty Reviews are review articles written by the prestigious Members of Faculty Opinions. The articles are commissioned and peer reviewed before publication to ensure that the final, published version is comprehensive and accessible. The reviewers who approved the final version are listed with their names and affiliations.

\section{The reviewers who approved this article are:}

\section{Version 1}

\section{Niranjan T. Kissoon}

Division of Critical Care, Department of Pediatrics, BC Children's Hospital and University of British

Columbia, Vancouver, BC, V6H 3V4, Canada

Competing Interests: No competing interests were disclosed.

\section{Margaret Parker}

Department of Pediatrics, State University of New York at Stony Brook, Stony Brook, NY, 11790-0988, USA

Competing Interests: No competing interests were disclosed.

\section{Gail Annich}

Department of Critical Care Medicine, Toronto Hospital for Sick Children, Toronto, ON, Canada

Competing Interests: No competing interests were disclosed.

The benefits of publishing with F1000Research:

- Your article is published within days, with no editorial bias

- You can publish traditional articles, null/negative results, case reports, data notes and more

- The peer review process is transparent and collaborative

- Your article is indexed in PubMed after passing peer review

- Dedicated customer support at every stage

For pre-submission enquiries, contact research@f1000.com 